\title{
MICROBIOLOGICAL CHARACTERIZATION OF RED AND WHITE WINES ORIGINATED FROM VINEYARDS OF GETIC PIEDMONT
}

\author{
Diana Ionela, STEGĂRUȘ \\ PhD Fellow, SOP HRD/159/1.5/S/133675 Project, ”Lucian Blaga” University of Sibiu, Sibiu, Romania, diana.stegarus@icsi.ro
}

\begin{abstract}
The aim of the present paper is to investigate an objective microbiological analysis of the wine by identification of some parameters such as total amount of germs and yeastswhich are contained in the quality wines from Getic Piedmont namely: Bolovanu, Corcova, Drăgășani, Sâmburești, Segarcea, Ștefănești.The Getic Piedmont is a relict geomorphological relief unit with significant variations from the flat, low lands fragmented by moderately rough with strong fragmentation. We have selected by grouping the wines in grape varieties, white wines (Sauvignon, Chardonnay, Riesling) and red wines (Merlot, Cabernet, Pinot noir) which were tested by microbiological tests. The opinion that the bacteria level should be acceptable in red wines and the yeasts level in white wines were supported by literature. The presence of these micro-organisms have clear influence in wine validity, in principle they are not detectable in a biologically pure wine.
\end{abstract}

KEY WORDS: white wines, red wines, NTG, UFC

\section{INTRODUCTION}

The microbiological quality of wines is an important aim in their preservation for longer time.

Ideally, the wines should be biologically pure, but this fact is impossible because of the micro-organisms which present a specific characteristic of living world, furthermore their isolation and identification is now possible through molecular advanced techniques (Târdea, 2010; Tiţa, 2004; Lengyel et al., 2012). This characteristic is adaptability to stress conditions and harsh environmental conditions. For micro-organisms the stress can be caused by $\mathrm{pH}$, chemical compounds found in wine storage and temperature conditions (Antoce et al., 2005; Antoce, 2007; Oprean et al., 2001). From the grapes, many bacteria reaches the young wine, where mostly is not a good environment for rising, especially because of the acidity and the alcohol content (Cotea et al., 2010; Batowski et al., 2003; Bartowski et al. , 2008; Pomohaci et al., 2000).

The most often bacteria found in wines are: Leuconostoc gracile, Bacillus viscosus vini, Bacillus amacrylus, Micrococus malolacticus, acetic bacteria, lactobacilli. These bacteria can develop some faults, if their number is high (Oprean et al. 2014; Antoce et al., 2007; Saliba et al., 2009; Tana et al., 2010; Ribereau-Gayón et al., 2000 ).

Lactic bacteria are malolactic fermentation agents, they are found mainly in young wines because of their presence it can happened to decrease the total acidity.

Malolactic fermentation is conditioned by the $\mathrm{pH}$ and the degree of sulphitation, having a positive role concerning red wines, because they have a high content of tannins, dyes and acids (malic acid) which give a bitter taste.
In the inappropriate filtered wines were highlighted the live yeast cells belong to the Saccharomyces, Rhodotorula, Candida and Pichia genre (Oprean et al., 2001; Croitoru, 2009).

\section{MATERIALS AND METHODS}

White wine samples (Sauvignon, Chardonnay, Riesling) and red (Merlot, Cabernet, Pinot noir) from vineyards Bolovanu centers, Corcova, Drăgăşani Sâmbureşti, Segarcea, Ştefăneşti with the acronym variety and origin.

Selective media for yeasts and bacteria:

Establishing the total number of yeasts

YEPD medium (yeast extract, peptone, dextrose) agar with chloramphenicol to inhibit bacterial activity (Scharlau, Gmbh, Barcelona).

Establishing the total number of bacteria

MRS agar medium, to act to inhibit the activity of yeasts (Scharlau, Gmbh, Barcelona).

In order to identify and counting of micro-organisms is applied the cultural method which involves the pipetting of $1 \mathrm{~mL}$ in a Petri plate, fill up with a liquefied culture medium and cooled at $45^{\circ} \mathrm{C}$.

The inoculated plates were incubated for bacteria at $25^{\circ} \mathrm{C}$ during 5 days and for yeasts at $25^{\circ} \mathrm{C}$ during 3 days. Counting is performed with a number of colonial sectors, depending on the microbial load (Vaz et al. 1995).

\section{RESULTS AND DISCUSSION}

The actual total number in the wine yeasts studied can give important information in terms of their stability over time. 
A large number of yeasts requires less adequate filtration, activation of yeasts in a favorable conditions, namely in the presence of of carbohydrates and other nutritional components lead to secondary fermentations or microbial alterations.
As shown in figure 1 the values determined present a minimum in the case of Chardonnay wines, originated from Corcova where has counted $129 \mathrm{CFU} / \mathrm{mL}$, and a maximum of 333UFC $/ \mathrm{mL}$ for wines originated from Ştefăneşti, variety Riesling.

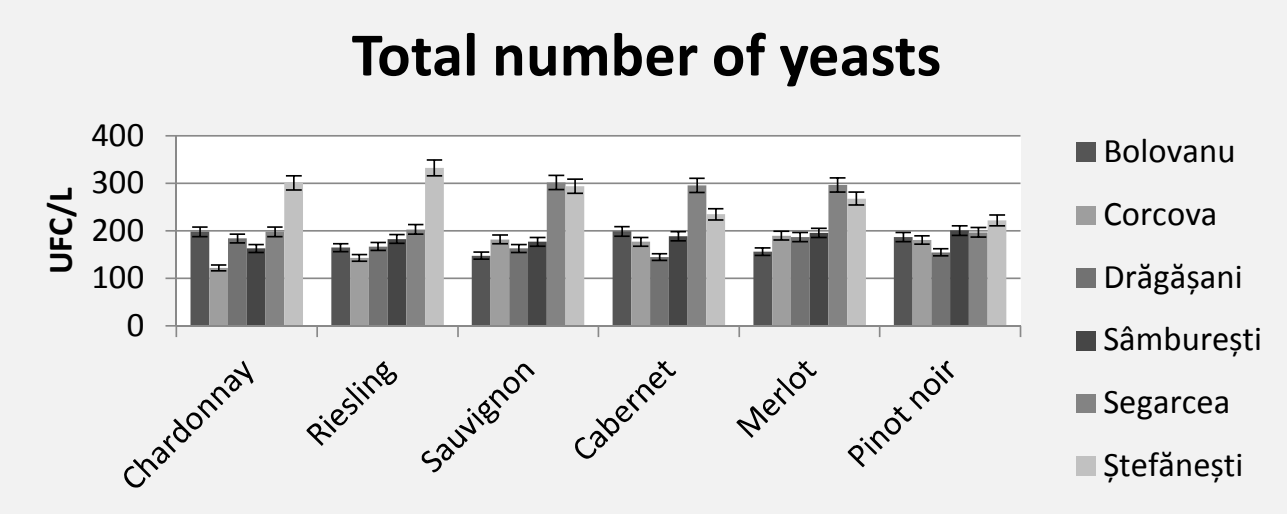

Figure 1. Total number of yeasts found in wines originated from Bolovanu, Corcova, Drăgăşani Sâmbureşti, Segarcea and Ştefăneşti

To identify the total number of bacteria is found similar values for white wines, instead of red wines where the values increase significantly.

It is notify a minimum developed colonies in the case of wine originated from Segarcea, (9 CFU / $\mathrm{mL}$ ) and a maximum of colonies developed for the wine originated from Ştefăneşti, variety Riesling (44 CFU/mL).
Media Centre Colonies developed in other vineyards is situated around $15 \mathrm{CFU} / \mathrm{mL}$, available value for white wines from Sauvignon, Chardonnay, Riesling varieties (Figure 2).

In the case of red wines is considered a dramatic increase of bacterial colonies number, the explanation should be the presence of malolactic bacteria in these wines.

In Figure 2 is observed that red wines from Sâmbureşti, Cabernet variety which present the most developed colonies (216 CFU / $\mathrm{mL})$, meanwhile in Segarcea can be observed a minimum of 26 $\mathrm{CFU} / \mathrm{mL}$.

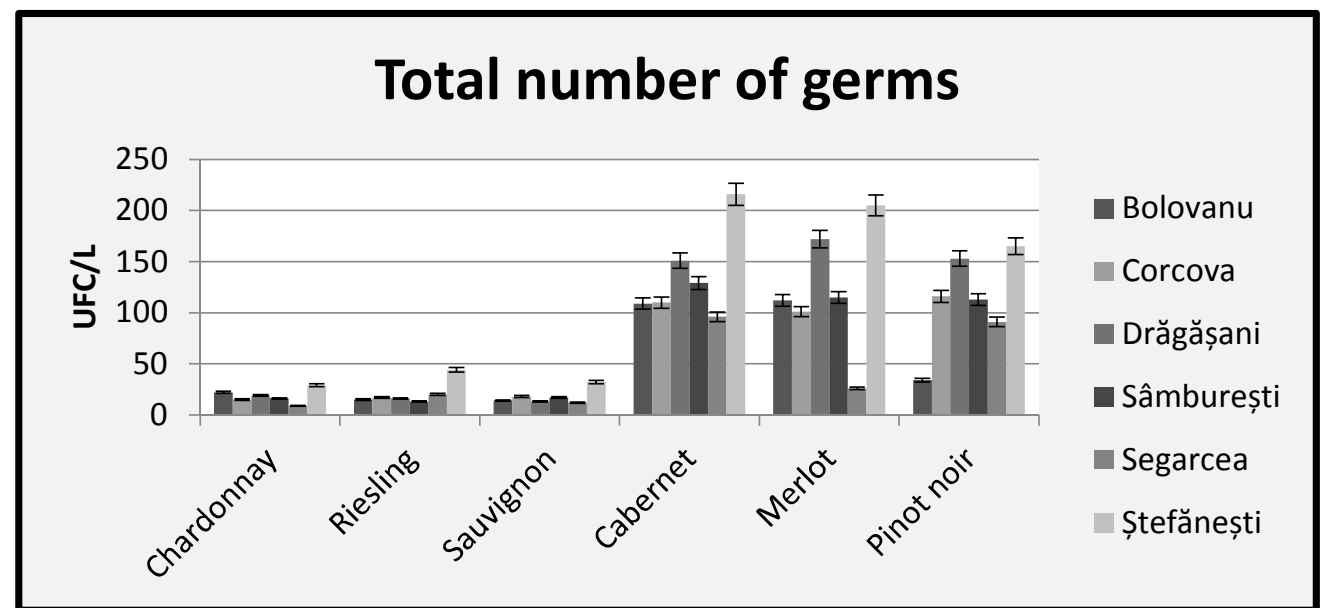

Figure 2. Total number of germs identified in wines from Bolovanu, Corcova, Drăgăşani Sâmbureşti, Segarcea and Ştefăneşti

From statistical analysis point of view the results it can be appreciated that the program error is zero, the values obtained for the system being considered significant. Figure 3 shows that the values obtained are arranged in the regression.

\begin{tabular}{cc}
\hline \multicolumn{2}{c}{ Regression Statistics } \\
\hline Multiple R & 1 \\
R Square & 1 \\
Adjusted R & \\
Square & 65535 \\
Standard & \\
Error & 0 \\
Observations & 6 \\
\hline
\end{tabular}




\begin{tabular}{cccccc}
\hline & df & SS & MS & F & $\begin{array}{c}\text { Significance } \\
\text { F }\end{array}$ \\
\hline Regression & 5 & 231.3333 & 46.26667 & \#NUM! & \#NUM! \\
Residual & 0 & 0 & 65535 & & \\
Total & 5 & 231.3333 & & & \\
\hline
\end{tabular}

\begin{tabular}{|c|c|c|c|c|c|c|c|}
\hline & \multicolumn{3}{|c|}{ Standard } & \multicolumn{3}{|r|}{ Upper } & \multirow{2}{*}{$\begin{array}{l}\text { Lower } \\
95,0 \% \\
\end{array}$} \\
\hline & Coefficients & Error & $\mathrm{t}$ Stat & $\mathrm{P}$-value & Lower $95 \%$ & $95 \%$ & \\
\hline Intercept & 8.114248 & 0 & 65535 & \#NUM! & 8.114248 & 8.114248 & 8.114248 \\
\hline X Variable 1 & 0.182139 & 0 & 65535 & \#NUM! & 0.182139 & 0.182139 & 0.182139 \\
\hline X Variable 2 & 0.10472 & 0 & 65535 & \#NUM! & 0.10472 & 0.10472 & 0.10472 \\
\hline X Variable 3 & 0.006584 & 0 & 65535 & \#NUM! & 0.006584 & 0.006584 & 0.006584 \\
\hline $\mathrm{X}$ Variable 4 & 0.104664 & 0 & 65535 & \#NUM! & 0.104664 & 0.104664 & 0.104664 \\
\hline X Variable 5 & -0.08096 & 0 & 65535 & \#NUM! & -0.08096 & -0.08096 & -0.08096 \\
\hline
\end{tabular}

RESIDUAL OUTPUT

\begin{tabular}{cccc}
\hline Observation & Predicted Y & Residuals & $\begin{array}{c}\text { Standard } \\
\text { Residuals }\end{array}$ \\
\hline 1 & 22 & 0 & 0 \\
2 & 15 & $1.78 \mathrm{E}-15$ & 0.745356 \\
3 & 19 & 0 & 0 \\
4 & 16 & $3.55 \mathrm{E}-15$ & 1.490712 \\
5 & 9 & $3.55 \mathrm{E}-15$ & 1.490712 \\
6 & 29 & 0 & 0 \\
\hline
\end{tabular}

PROBABILITY OUTPUT

\begin{tabular}{cc}
\hline Percentile & $\mathrm{Y}$ \\
\hline 8.333333 & 9 \\
25 & 15 \\
41.66667 & 16 \\
58.33333 & 19 \\
75 & 22 \\
91.66667 & 29 \\
\hline
\end{tabular}

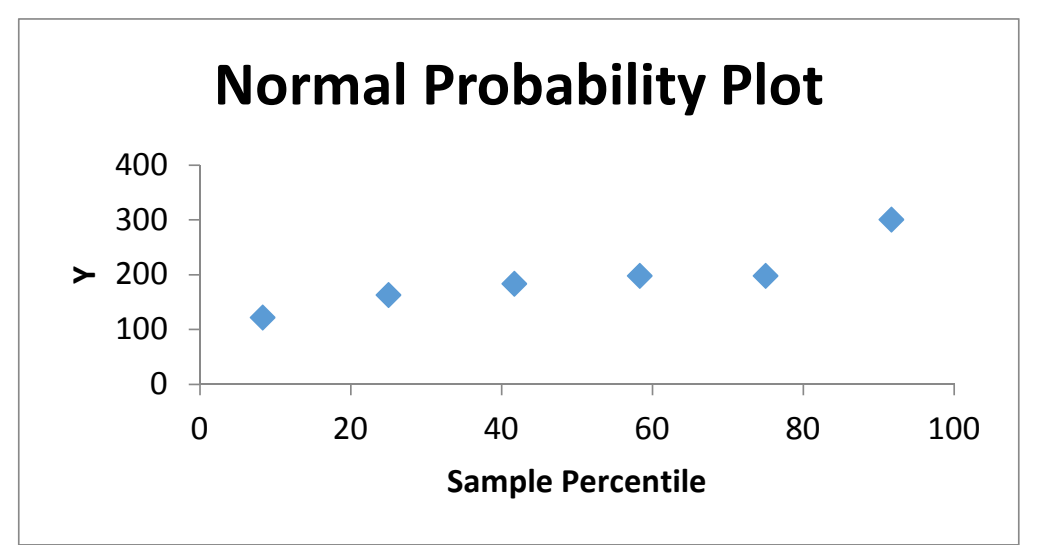

Figure 3. Regression curve for the wines submitted to statistical analysis

\section{CONCLUSION}

A particular importance for the stability of the wine it has the filtering process, where micro-organisms do not reach the bottled wine.

From the results it show up that the in the studied wines arise both bacteria (germs total) and yeasts, which leads to the conclusion that practicaly all these wines have slightly technology faults, imposing more rigorous filtering of the wine.

Depending on the number of micro-organisms detected can be estimated also the validity time, a small number can be accepted due to the fact that some of these micro-organisms will not occur to chemical stress present in the wine caused by its biochemical complexity.

\section{ACKNOWLEDGEMENT}

This paper is supported by the Sectoral Operational Programme Human Resources Development (SOP HRD), financed from the European Social Fund and by the Romanian Government under the contract number POSDRU/159/1.5/133675

\section{REFERENCES}

1. Antoce Arina Oana, 2007 - Oenologie (Chimie și analiză senzorială), Editura Universitaria, Craiova 
2. Antoce Arina Oana, Nămoloșanu Ioan, 2005 - Oenologie (Controlul și prevenirea fraudelor), Editura Ceres, București

3. Antoce Arina Oana, Nămoloșanu Ioan, 2007 - Oenologie Defectele și bolile vinului - (recunoaștere și metode de stabilizare), AMC - UȘAMV, București

4. Bartowsky, E. J., and Henschke, P.A. (2008) Acetic acid bacteria spoilage of bottled red wine- A review. International Journal of Food Microbiology 125, 60-70

5. Bartowsky, E. J., Xia, D., Gibson, R.L., Fleet, G.H. and Henschke, P.A. (2003) Spoilage of bottled red wine by acetic acid bacteria, Letters in Applied Microbiology 36, 307-314

6. Cotea V. D., Zănoagă C.Z., Cotea Valeriu V., (2010), Tratat de oenochimie, vol. I Editura Academiei Române, București

7. Croitoru Constantin, (2009) - Tratat de știință și inginerie oenologică (Produse de elaborare și maturare a vinurilor), Editura AGIR, București

8. Lengyel, E., Letitia Oprean, O.Tita, Mariana-Liliana Păcală, Ramona Iancu, Diana Stegarus, O.Ketney, (2012), Isolation and molecular identifications of wine yeast strains from autochthonous aromatic and semiaromatic varieties, Annals of RSCB, Vol. XVII, ( 2) pp. 134-138

9. Oprean L., Tița, O., Analiza microbiologică a vinului, Ed. Univ. „Lucian Blaga”, Sibiu, 2001
10. Oprean Letitia, Iancu Ramona Maria, Ecaterina Lengyel,(2014), Microbiologie alimentară : note de curs, Ed. Universităţii Lucian Blaga Sibiu

11. Pomohaci N., Stoian V., Gheorghiță M., Sîrghi C., Cotea V. V., Nămoloșanu I., 2000 - Oenologie vol. I, Prelucrarea strugurilor și producerea vinurilor, Editura Ceres, București

12. Ribéreau-Gayon, J., Peynaud, E., Ribéreau-Gayon, P., Sudraud, P.,(2000), Traité d'oenologie, Sciences et Techniques du Vin, tome 3, Ed. Dunod, Paris

13. Saliba, A.J., Bullock, J. and Hardie, W.J. (2009) Consumer rejection threshold for 1, 8-cineole (eucalyptol) in Australian red wine. Food Quality and Preference 20, 500504

14. Tana, M., C., Maria Cosmina Marginean, Ovidiu Tita, Ecaterina Lengyel, (2010), Diseases and defects in wine phenomena of contamination, International Conference Agricultural and Food Sciences, Processes and Technologies, pp.21-27

15. Tiţa Ovidiu, 2004, Tehnologii de obţinere a vinurilor, Editura Universităţii Lucian Blaga din Sibiu

16. T,ârdea C., Sârbu Ghe., T,ârdea A., (2010), Tratat de vinificație, Editura Ion Ionescu de la Brad, Iași

17. Vaz Oliveira, M., Barros, Loureiro, V. (1995). Analyse microbiologique du vin. Technique des tubes multiples pour l'énumération de micro-organismes dans les vins - "Nombre le plus probable" (NPP), F.V.O.I.V. n 987, Paris (2009). 